\title{
InGaN/GaN multiple quantum well concentrator solar cells
}

\author{
R. Dahal, J. Li, K. Aryal, J. Y. Lin, and H. X. Jiang ${ }^{\text {a) }}$ \\ Department of Electrical and Computer Engineering, Texas Tech University, Lubbock, Texas 79409, USA
}

(Received 8 July 2010; accepted 1 August 2010; published online 19 August 2010)

\begin{abstract}
We present the growth, fabrication, and photovoltaic characteristics of $\operatorname{In}_{\mathrm{x}} \mathrm{Ga}_{1-\mathrm{x}} \mathrm{N} / \mathrm{GaN}(\mathrm{x} \sim 0.35)$ multiple quantum well solar cells for concentrator applications. The open circuit voltage, short circuit current density, and solar-energy-to-electricity conversion efficiency were found to increase under concentrated sunlight. The overall efficiency increases from $2.95 \%$ to $3.03 \%$ when solar concentration increases from 1 to 30 suns and could be enhanced by further improving the material quality. (C) 2010 American Institute of Physics. [doi:10.1063/1.3481424]
\end{abstract}

The direct and tunable band gap of InGaN alloys with high band edge absorption $\left(10^{5} \mathrm{~cm}^{-1}\right)$ is very attractive for designing multijunction solar cells for both terrestrial and space-based applications. Furthermore, InGaN alloys have the advantages of high carrier mobility, high drift velocity, high temperature, and radiation resistance, which will all contribute to the realization of highly efficient solar cells for potential use under concentrated sunlight. ${ }^{1-6}$ Recent progress in the growth of both n-type and p-type high In-content InGaN alloys without phase separation will also open up new opportunities for InGaN based thin film photovoltaic device research. $^{7-12}$

An earlier theoretical calculation indicated that the requirements of an active material system for obtaining solar cells with a solar energy conversion efficiency greater than $50 \%$ can be fulfilled by InGaN alloys with In-content of about $40 \% .^{13}$ Additionally, III-nitride multi-junction solar cells with near ideal band gaps for maximum solar energy conversion efficiency must incorporate InGaN layers with higher In contents or lower energy band gaps. However, the realization of solar cells with high In content is highly challenging. One of the biggest problems is attributed to the large lattice mismatch between $\mathrm{InN}$ and $\mathrm{GaN}$, resulting in phase separation. As a consequence, the reported values of open circuit voltages $\left(\mathrm{V}_{\text {oc }}\right)$ for different In contents (up to $15 \%$ ) in general are significantly lower than the theoretical values (thermodynamic limit). For example, the experimentally observed $\mathrm{V}_{\text {oc }}$ for $\mathrm{In}_{0.15} \mathrm{Ga}_{0.85} \mathrm{~N}\left(\mathrm{E}_{\mathrm{g}} \sim 3 \mathrm{eV}\right)$ based solar cells was $\sim 0.9 \mathrm{~V}$, which is much lower than the theoretical value of $2.52 \mathrm{~V}^{12}$ Lower $\mathrm{V}_{\text {oc }}$ values in InGaN solar cells with higher In contents are not only caused by the lowering of the band gaps but are also related to reduced crystalline quality ${ }^{11,12}$

More recently, our group has shown that by directly depositing on GaN or AlN epitemplates without buffer layers, single phase InGaN epilayers across the entire alloy range can be produced by metal organic chemical vapor deposition (MOCVD). ${ }^{1}$ Evidence that strain could suppress phase separation in InGaN has been reported by various groups..$^{14,15}$ Utilizing the idea of suppressing phase separation by strain engineering, we recently demonstrated the operation of $\mathrm{In}_{\mathrm{x}} \mathrm{Ga}_{1-\mathrm{x}} \mathrm{N} / \mathrm{GaN}(\mathrm{x} \sim 0.3)$ multiple quantum well (MQW) solar cells with long operating wavelength up to $450 \mathrm{~nm} .{ }^{10}$

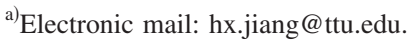

The advantages of these low dimensional InGaN MQW solar cells include (i) the crystalline quality of the thin light absorption layers ( $\mathrm{InGaN}$ wells) embedded between $\mathrm{GaN}$ barriers is higher than that of InGaN epilayers with thickness exceeding the critical thickness, (ii) with the incorporation of MQW structure in the i-region, $V_{\mathrm{oc}}$ and $\mathrm{J}_{\mathrm{sc}}$ can be independently optimized. $\mathrm{V}_{\mathrm{oc}}$ is primarily determined by the wider band gap barrier material while spectral response is determined by the width and depth of the lower band gap material, QWs. Thus, if the current and voltage are independently optimized, the conversion efficiency could exceed the efficiency limit of a conventional homojunction single-gap solar cell, and (iii) MQW solar cells are expected to outperform bulk i-layer solar cells under concentrated sunlight. ${ }^{16}$ There are only a few reports on InGaN/GaN MQW solar cells so far $^{10,17-19}$ and most measurements were performed under 1 sun illumination. ${ }^{15-17}$ In this letter, we report on the growth and fabrication of $\operatorname{In}_{\mathrm{x}} \mathrm{Ga}_{1-\mathrm{x}} \mathrm{N} / \mathrm{GaN} \mathrm{MQW}(\mathrm{x} \sim 0.35)$ solar cells for concentrator applications.

The solar cell layer structure was modified based on our previous work ${ }^{10}$ and is illustrated in Fig. 1(a). The light absorbing region consists of twelve periods of $\operatorname{In}_{\mathrm{x}} \mathrm{Ga}_{1-\mathrm{x}} \mathrm{N}$ (3 $\mathrm{nm}) / \mathrm{GaN}(16 \mathrm{~nm}) \mathrm{MQWs}$. The MQWs were grown under the established MOCVD growth conditions of $\operatorname{In}_{\mathrm{x}} \mathrm{Ga}_{1-\mathrm{x}} \mathrm{N}$ epilayer $^{7}$ with targeted $\mathrm{x}$ values of around 0.35 . The thickness of $p$-GaN $(n-\mathrm{GaN})$ is $\sim 400 \mathrm{~nm}(\sim 1 \mu \mathrm{m})$. The device structure was grown on a GaN epilayer $(3 \mu \mathrm{m}) /$ sapphire template and exhibits a predominant electroluminescence emission peak around $533 \mathrm{~nm}$. The device fabrication processes include the following steps: (1) deposition of a thin bilayer of $\mathrm{Ni} / \mathrm{Au}(3 / 6 \mathrm{~nm})$ by e-beam evaporation; (2) devices with mesa size dimensions of $2.3 \times 2 \mathrm{~mm}^{2}$ were defined by etching down to n-type $\mathrm{GaN}$ using chlorine based inductively coupled plasma technique; (3) the semitransparent p-contact was annealed for $30 \mathrm{~min}$ in air at $450{ }^{\circ} \mathrm{C}$ to obtain the Ohmic characteristic for p-contact; (4) grid p-contact Ni/Au electrode (6 $\mu \mathrm{m}$ width and pitch distance of $170 \mu \mathrm{m})$ bilayers $(30 / 150 \mathrm{~nm}$ in thickness) were deposited on the mesa area; (5) Ti/Al/Ni/Au (30/100/20/150 nm) n-contact was deposited by e-beam evaporation using optical lithography and lift-off technique; (6) antireflection coating of $100 \mathrm{~nm} \mathrm{SiO}_{2}$ was deposited by plasma enhanced chemical vapor deposition and contact windows were opened by lithography combined with wet etching of $\mathrm{SiO}_{2}$, and finally (7) an aluminum back reflector $(300 \mathrm{~nm})$ was deposited on the sapphire side. The optical microscopy image of a fabricated 
p-contact pad
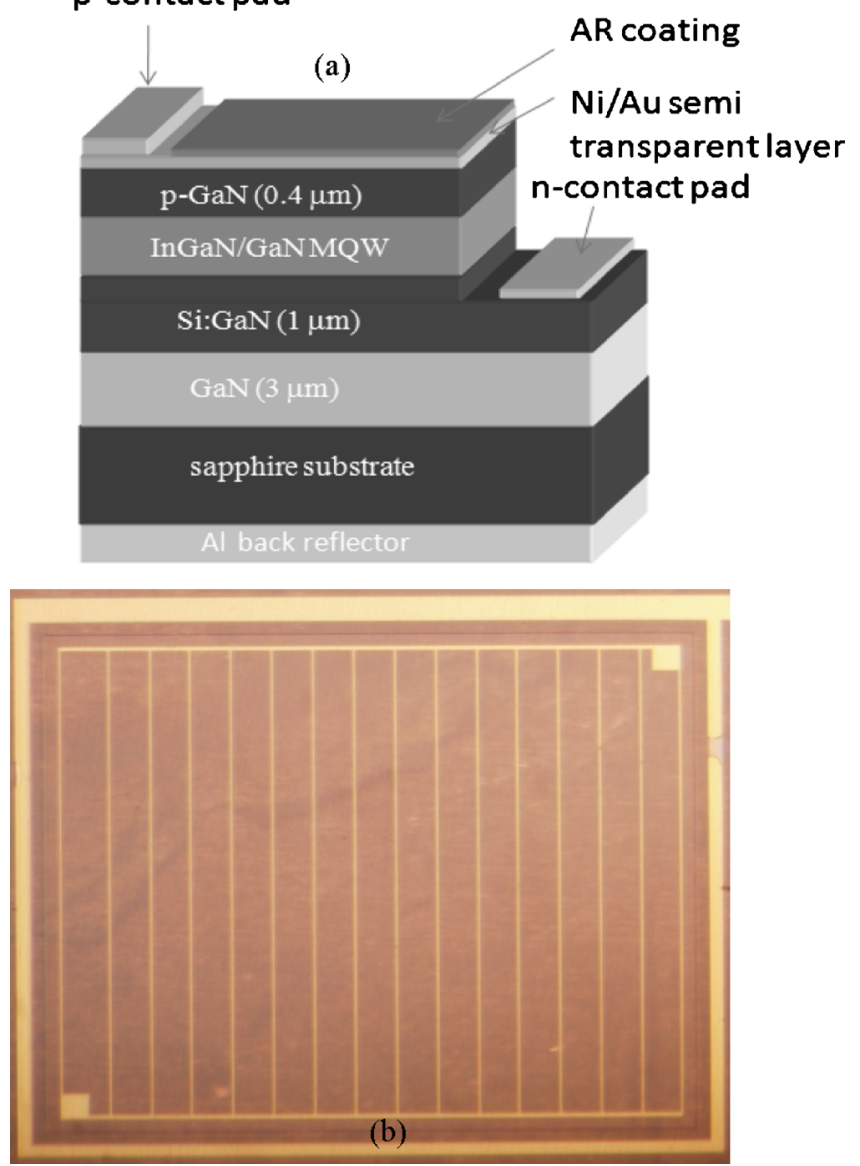

FIG. 1. (Color online) (a) Layer structure of InGaN/GaN solar cells with twelve periods of $3 \mathrm{~nm}$ thick $\operatorname{In}_{\mathrm{x}} \mathrm{Ga}_{1-\mathrm{x}} \mathrm{N}(\mathrm{x} \approx 0.35) \mathrm{QW}$ and $17 \mathrm{~nm} \mathrm{GaN}$ barrier, and (b) optical microscopy image of a fabricated solar cell with $2.3 \times 2 \mathrm{~mm}^{2}$ mesa size.

solar cell is shown in Fig. 1(b). The devices were characterized using a microprobe station, air mass 1.5 solar simulator and Keithley 2400 source meter.

Figure 2 shows the current density versus voltage $\left(\mathrm{J}_{\mathrm{sc}}-\mathrm{V}\right)$ and power density versus voltage $(\mathrm{P}-\mathrm{V})$ characteristics of a

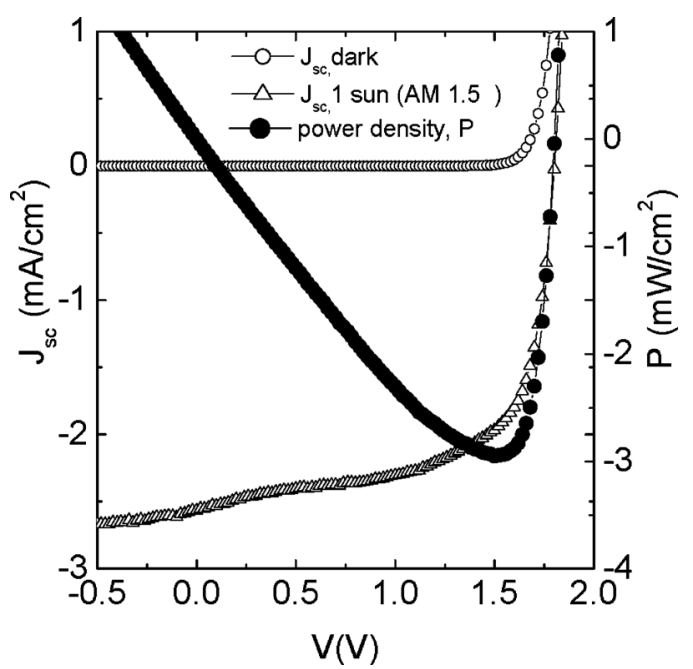

FIG. 2. Room temperature current density versus voltage $\left(\mathrm{J}_{\mathrm{sc}}-\mathrm{V}\right)$ and power density versus voltage (P-V) characteristics of $\operatorname{In}_{\mathrm{x}} \mathrm{Ga}_{1-\mathrm{x}} \mathrm{N} / \mathrm{GaN}$ MQW (x $\sim 0.35$ ) solar cells under AM 1.5 irradiation. $\mathrm{V}_{\mathrm{oc}}, \mathrm{J}_{\mathrm{sc}}, \mathrm{FF}$ and $\eta$ are $1.8 \mathrm{~V}$, $2.56 \mathrm{~mA} / \mathrm{cm}^{2}, 64 \%$ and $2.95 \%$, respectively. fabricated $\mathrm{In}_{\mathrm{x}} \mathrm{Ga}_{1-\mathrm{x}} \mathrm{N} / \mathrm{GaN} \mathrm{MQW}$ solar cell under air mass 1.5 (1.5 a.m.) irradiation $\left(\mathrm{I}_{\mathrm{int}} \sim 100 \mathrm{~mW} / \mathrm{cm}^{2}\right)$. From these measurements, $\mathrm{V}_{\mathrm{oc}}, \mathrm{J}_{\mathrm{sc}}$, fill factor $(\mathrm{FF})$, and maximum power delivered by the devices were found to be $1.80 \mathrm{~V}$, $2.56 \mathrm{~mA} / \mathrm{cm}^{2}, 64 \%$, and $2.95 \mathrm{~mW} / \mathrm{cm}^{2}$, respectively. The values of $\mathrm{V}_{\mathrm{oc}}, \mathrm{J}_{\mathrm{sc}}, \mathrm{FF}$ are significantly higher than previously reported values for InGaN/GaN MQWs solar cells with similar In content in the QWs. ${ }^{15-17}$ The improvements can be attributed to the higher quality of InGaN material in MQWs. The overall solar to electrical power conversion efficiency $(\eta)$ of the device is $2.95 \%$, which is still much lower than the theoretically expected value of a single junction solar cell of about $8 \%$ at this optical energy band gap. One of the reasons is attributed to the insufficient thickness of the light absorbing layer in InGaN wells (total InGaN thickness $\sim 36 \mathrm{~nm}$ ) which should, at the least, be greater than $200 \mathrm{~nm}$ for complete light absorption. This was evidenced by the increase in photocurrent density by more than $15 \%$ when an aluminum back reflector was deposited. However, obtaining InGaN/ GaN MQW structures with a total InGaN light absorption layer thickness of around $200 \mathrm{~nm}$ is another challenging task.

We have also studied the light intensity, $\mathrm{I}_{\text {int }}$, dependence of $\mathrm{J}_{\mathrm{sc}}, \mathrm{V}_{\mathrm{oc}}, \mathrm{FF}$ and $\eta$ to explore the potential use of InGaN MQW for concentrator solar cells. Figure 3 shows $\mathrm{J}_{\mathrm{sc}}-\mathrm{V}$ curves for different solar concentration, $\mathrm{C}$ and Fig. 3(b) shows the plot of $\mathrm{J}_{\mathrm{sc}}$ as a function of $\mathrm{C}$ up to 30 suns. The short circuit current density increases linearly with solar concentration at a slope of about $2.48 \mathrm{~mA} / \mathrm{cm}^{2} /$ sun, which was as expected because the number of charge carrier generated is directly proportional to the number of photons absorbed. The solar conversion efficiency enhancement in a solar cell under the influence of concentrated sun light is due to the increase in $\mathrm{V}_{\text {oc }}$ of the cell. $\mathrm{V}_{\mathrm{oc}}$ as a function of $\mathrm{C}$ can be expressed as $^{20}$

$$
\mathrm{V}_{\mathrm{oc}}(\mathrm{C}) \approx \mathrm{V}_{\mathrm{oc}}(1)+\left(\mathrm{nK}_{\mathrm{B}} \mathrm{T} / \mathrm{q}\right) \ln (\mathrm{C}),
$$

where $V_{o c}(1)$, $n$, and $K_{B}$ are open circuit voltage under 1 sun illumination, diode ideality factor, and Boltzmann constant, respectively. According to Eq. (1), $\mathrm{V}_{\mathrm{oc}}$ should increase logarithmically with $\mathrm{C}$ and $\eta$ should be enhanced by an amount of $\left[\mathrm{nK}_{\mathrm{B}} \mathrm{T} / \mathrm{qV}_{\mathrm{oc}}(1)\right] \ln \mathrm{C}$ if $\mathrm{FF}$ remains unchanged.

Figure 4(a) shows the plots of $\mathrm{V}_{\mathrm{oc}}$ (left axis) and FF (right axis) as functions of $\mathrm{C} . \mathrm{V}_{\mathrm{oc}}$ increases logarithmically with $C$. However, the experimentally measured values of $V_{o c}$ for different values of $\mathrm{C}$ were lower than the calculated values using Eq. (1) [solid line in Fig. 4(a)]. The difference in experimentally observed values of $\mathrm{V}_{\mathrm{oc}}$ and calculated values using Eq. (1) is due to the decrease in FF with increasing C, as Eq. (1) is valid only when FF remains constant. FF decreases from $64 \%$ to $57 \%$ when $\mathrm{C}$ increases from 1 to 30 , as shown in Fig. 4. The decrease in FF with increasing $\mathrm{C}$ is related to the enhanced carrier recombination at the interface region due to high carrier densities under concentrated sunlight. We have also plotted $\eta$ as a function of $\mathrm{C}$ in Fig. 4(b). The efficiency increases from $2.95 \%$ to $3.03 \%$ when $\mathrm{C}$ increases from 1 to 30 suns. The percentage increase in $\eta$ is $2.7 \%$ whereas the percentage increase in $\mathrm{V}_{\mathrm{oc}}$ is $\sim 8 \%$. According to Eq. (1), $\eta$ should have been increased by a factor of 1.11 (or $11 \%$ ). The lower percentage increase in $\eta$ with $\mathrm{C}$ than prediction by Eq. (1) is also due to the decrease in the FF with increasing C. However, the results indicate the 

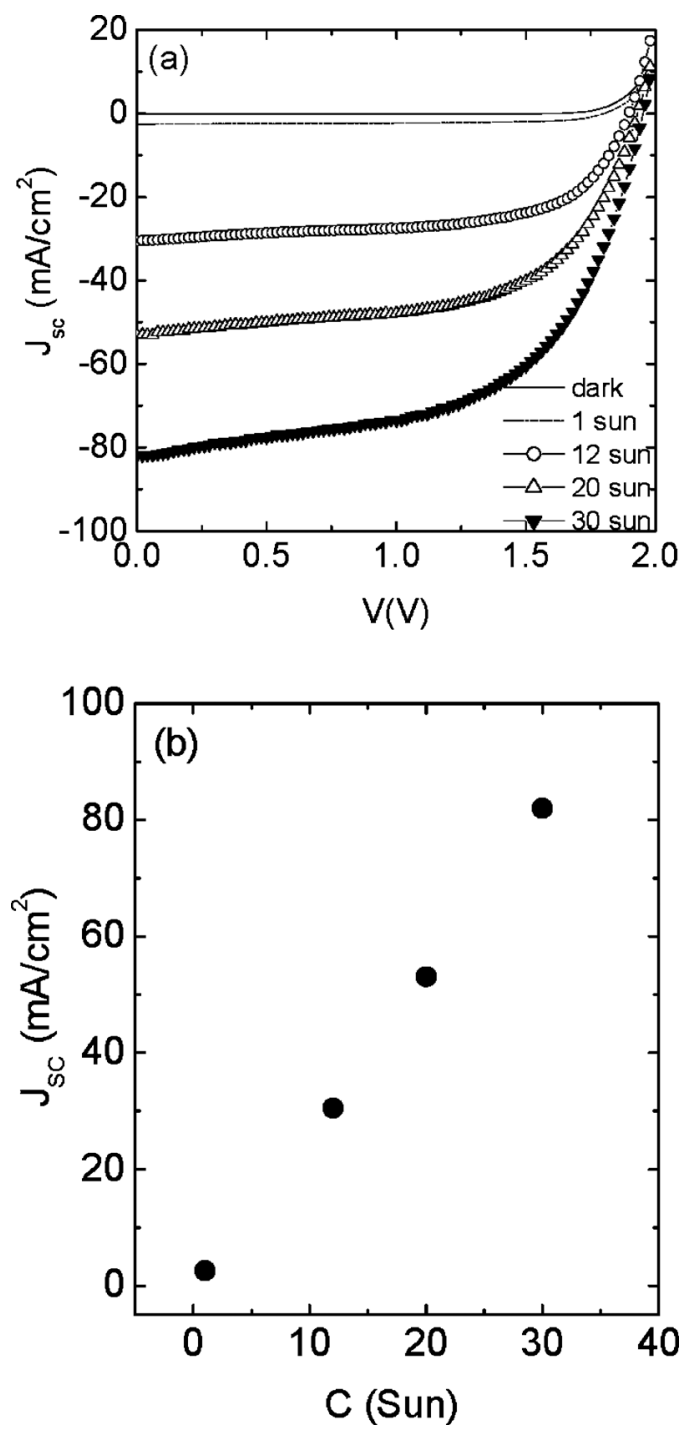

FIG. 3. (a) $\mathrm{J}_{\mathrm{sc}}-\mathrm{V}$ curves of $\mathrm{In}_{\mathrm{x}} \mathrm{Ga}_{1-\mathrm{x}} \mathrm{N} / \mathrm{GaN} \mathrm{MQW}(\mathrm{x} \sim 0.35)$ solar cells under irradiation of different levels of solar light concentration, $\mathrm{C}$, and (b) $\mathrm{J}_{\mathrm{sc}}$ as a function of $\mathrm{C}$, which shows a linear increasing of $\mathrm{J}_{\mathrm{sc}}$ with solar concentration $\mathrm{J}_{\mathrm{sc}}$
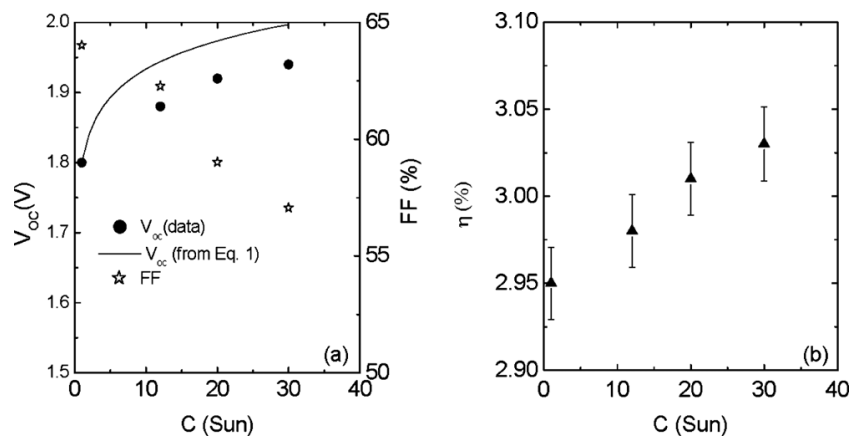

FIG. 4. (a) $\mathrm{V}_{\mathrm{oc}}$ and $\mathrm{J}_{\mathrm{sc}}$ as functions of solar concentration, C. $\mathrm{V}_{\mathrm{oc}}$ increases logarithmically with $C$. In order to calculate the values of $V_{o c}$ using Eq. (1), experimentally measured value of $\mathrm{V}_{\mathrm{oc}}(1)=1.80 \mathrm{~V}$ and diode ideality factor, $\mathrm{n}=2.24$ determined from dark $\mathrm{J}_{\mathrm{sc}}-\mathrm{V}$ curve were used. (b) Solar-energy-toelectricity conversion efficiency, $\eta$, as a function of solar concentration, C. The efficiency increases from $2.95 \%$ to $3.03 \%$ as $\mathrm{C}$ increases from 1 to 30 suns. strong potential of InGaN based MQW solar cells for concentrated photovoltaic applications.

In summary, InGaN/GaN MQW solar cells with In concentration greater than $30 \%$ in QWs were fabricated and photovoltaic properties were studied under concentrated sun light (up to 30 suns). The open circuit voltage and efficiency of the cells were found to increase with increasing light intensity, though the FF of solar cells decreases with increasing intensity up to 30 suns. The lower enhancement in overall efficiency than the theoretical expectation is due to a decrease in the fill factor, which is attributed to increasing interfacial charge density with concentrated light leading to higher recombination of charge carriers. However, the results revealed the potential of InGaN based solar cells for concentrated PV applications. The efficiency under concentrated sunlight could be further enhanced by improving the interfacial quality between InGaN and GaN by reducing the dislocation density at the interface through further growth and device processing optimization.

This research was supported by NSF (Grant No. DMR0906879). Jiang and Lin gratefully acknowledge the support of the Whitacre Endowed Chair positions by the AT \& T Foundation.

${ }^{1}$ M. Funato, M. Unde, Y. Kawakami, Y. Narukawa, T. Kosugi, M. Takanashi, and T. Mukai, Jpn. J. Appl. Phys., Part 2 45, L659 (2006).

${ }^{2}$ T. Lu, C. Kao, H. Kuo, G. Huang, and S. Wang, Appl. Phys. Lett. 92, 141102 (2008).

${ }^{3}$ O. Jani, I. Ferguson, C. Honsberg, and S. Kurtz, Appl. Phys. Lett. 91, 132117 (2007).

${ }^{4}$ J. Wu, W. Walukiewich, K. M. Yu, W. Shan, J. W. Ager, E. E. Haller, H. Lu, W. J. Schaff, W. K. Metzger, and S. Kurtz, J. Appl. Phys. 94, 6477 (2003).

${ }^{5}$ Y. Nanishi, Y. Satio, and T. Yamaguchi, Jpn. J. Appl. Phys., Part 1 42, 2549 (2003)

${ }^{6}$ M. Vázquez, C. Algora, I. Rey-Stolle, and J. R. Gonzalez, Prog. Photovoltaics 15, 477 (2007)

${ }^{7}$ B. N. Pantha, J. Li, J. Y. Lin, and H. X. Jiang, Appl. Phys. Lett. 93 182107 (2008).

${ }^{8}$ B. N. Pantha, A. Sedhain, J. Li, J. Y. Lin, and H. X. Jiang, Appl. Phys. Lett. 95, 261904 (2009).

${ }^{9}$ B. N. Pantha, A. Sedhain, J. Li, J. Y. Lin, and H. X. Jiang, Appl. Phys. Lett. 96, 232105 (2010).

${ }^{10}$ R. Dahal, B. Pantha, J. Li, J. Y. Lin, and H. X. Jiang, Appl. Phys. Lett. 94, 063505 (2009).

${ }^{11}$ X. Cai, S. Zeng, and B. Zhang, Appl. Phys. Lett. 95, 173504 (2009).

${ }^{12}$ M. Carmody, S. Mallick, J. Margetis, R. Kodama, T. Biegala, D. Xu, P. Bechmann, J. W. Garland, and S. Sivananthan, Appl. Phys. Lett. 96 153502 (2010).

${ }^{13}$ A. De Vos, Endoreversible Thermodynamics of Solar Energy Conversion (Oxford University Press, Oxford, 1992), p. 90.

${ }^{14}$ R. Singh, D. Doppalapudi, T. D. Moustakas, and L. T. Romano, Appl. Phys. Lett. 70, 1089 (1997).

${ }^{15}$ A. Tabata, L. K. Teles, L. M. R. Scolfaro, J. R. Leite, A. Kharchenko, T. Frey, D. J. As, D. Schikora, K. Lischka, J. Furthmuller, and F. Bechstedt, Appl. Phys. Lett. 80, 769 (2002).

${ }^{16}$ H. Ohtsuka, T. Kitatani, Y. Yazawa, and T. Warabisako, Sol. Energy Mater. Sol. Cells 50, 251 (1998).

${ }^{17}$ K. Y. Lai, G. J. Lin, Y. L. Lai, Y. F. Chen, and J. H. He, Appl. Phys. Lett. 96, 081103 (2010).

${ }^{18}$ I. M. Pryce, D. D. Koleske, A. J. Fisher, and H. A. Atwater, Appl. Phys. Lett. 96, 153501 (2010).

${ }^{19}$ M. Jeng, Y. Lee, and L. Chang, J. Phys. D: Appl. Phys. 42, 105101 (2009).

${ }^{20}$ T. Tromholt, E. A. Katz, B. Hirsch, A. Vossier, and F. C. Krebs, Appl. Phys. Lett. 96, 073501 (2010). 